\title{
A publicidade social sobe e desce o morro: a pesquisa do LACCOPS (Laboratório de Investigação em Comunicação Comunitária e Publicidade Social) aplicada ao projeto pedagógico da AÊ!UfF (Agência Experimental da UFF)
}

\author{
SOCIAL ADVERTISING GOES UP AND DOWN MORRO \\ LACCOPS (RESEARCH LABORATORY IN COMMUNITY COMMUNICATION AND \\ SOCIAL ADVERTISING) APPLIED TO THE PEDAGOGICAL PROJECT OF AÊ! UFF \\ (EXPERIMENTAL AGENCY OF UFF)
}

\section{Pablo Nabarrete Bastos}

Professor Adjunto I do Departamento de Comunicação Social, do Instituto de Arte e Comunicação Social da Universidade Federal Fluminense. Professor permanente do Programa de PósGraduação em Mídia e Cotidiano (PPGMC). Vice-coordenador pedagógico do Laboratório de Pesquisa em Comunicação Comunitária e Publicidade Social (LACCOPS). Vice-coordenador do GP Comunicação para a Cidadania da Intercom. Doutor em Ciências da Comunicação, linha de pesquisa de Comunicação, Cultura e Cidadania, pela ECA-USP. Publicou capítulos de livros, artigos e participou de congressos, seminários, encontros e grupos de pesquisa sobre comunicação, cultura, comunicação alternativa, culturas populares e política. Possui experiência profissional nas áreas de Planejamento de Campanha e Redação Publicitária, com atuação em agência de comunicação e no terceiro setor.

E-mail: pablobastos@hotmail.com

\section{Patrícia Gonçalves Saldanha}

Professora Associada I do curso de Publicidade e Propaganda do Instituto de Arte e Comunicação Social da Universidade Federal Fluminense. Professora permanente do PPGMC, Coordenadora Geral do LACCOPS. Doutora em Comunicação e Cultura pela Eco- UFRJ. Possui experiência profissional nas áreas de Atendimento, Planejamento de Campanha, Administração de Agência de Publicidade (pequeno, médio e grande porte), Treinamento, com forte atuação no terceiro setor. E-mail: patsaldanhappgmc@gmail.com 


\section{Resumo}

O objetivo aqui é expor o processo de consubstanciação de pesquisas desenvolvidas em projetos que atuam simultânea e complementar no curso de graduação em Comunicação Social: o LACCOPS (Laboratório de Investigação em Comunicação Comunitária e Publicidade Social), grupo de pesquisa ligado ao PPGMC - Programa de Pós-Graduação em Mídia e Cotidiano, que congrega alunos de pós e de graduação e a AẾUFF (Agência de Publicidade Experimental UFF). O foco é explicitar a metodologia de trabalho da Agência, coordenada pelos autores deste capítulo, destacando campanhas desenvolvidas em 2017.

Palavras-chave: Publicidade Social. Metodologias de ensino-aprendizagem. Laccops. AÊ-UFF.

\section{Abstract}

The objective here is to expose the process of consubstantiation of researches developed in projects that simultaneously and complement the undergraduate degree in Social Communication: LACCOPS (Laboratory of Research in Community Communication and Social Publicity), research group linked to the PPGMC - Graduate in Media and Daily Life, which brings together postgraduate and graduate students and AÊ! UFF (Experimental Advertising Agency UFF). The focus is to clarify the Agency's work methodology, coordinated by the authors of this chapter, highlighting campaigns developed in 2017.

Keywords: Social Advertising. Teaching and learning methodologies. Laccops. Â̂-UFF.

\section{Introdução}

Um dos debates em evidência nos cursos de graduação e de pós-graduação da Comunicação Social atuais é sobre o equilíbrio entre sua legitimidade científica e sua importância social, uma vez que o termo "Social" nomeia o campo. A discussão se dá em âmbito geral no que tange à área, mas também circula em terrenos específicos, como é o caso do subcampo "Publicidade e Propaganda". Recentemente, um dos mais importantes teóricos que pesquisam sobre o tema, o Professor Muniz Sodré, lançou uma obra com uma proposta epistemológica que reforça a ideia de objeto ${ }^{1}$, além de sugerir uma metodologia consistente para consolidação do campo comunicacional, A Ciência do Comum: notas para o método comunicacional (2015).

Em linhas gerais, trata-se de um campo multidisciplinar que está organizado em três níveis operacionais: o vinculativo, que tem a ver com as relações humanas em níveis interpessoais profundos; o relacional, que abrange as relações contratuais, numa camada epidérmica que considera as atividades de mercado e, por fim, o crítico-cognitivo, se dá no espaço acadêmico e se dedica a refletir e a compreender as dinâmicas comunicacionais

1. Que já vem sendo trabalhada desde a virada para o século atual no livro Antropológica do Espelho (2000). 
referentes às novas cognições, aos avanços tecnológicos, à reorganização política e aos impactos na reestruturação dos costumes cotidianos. Tais níveis operacionais resultam em diversidades temáticas que precisam ser investigadas, já que contribuem com o rearranjo da Sociedade Civil. Ou seja, estamos tratando de um campo composto por uma pluralidade de especializações ${ }^{2}$ presentes e naturalizadas na rotina do cidadão comum. Nesse sentido, os cursos de Comunicação Social do Ensino Superior são primordiais para estimular o engajamento dos indivíduos em dinâmicas voltadas à leitura crítica das mensagens divulgadas pela mídia. Logo, o estímulo ao engajamento se concretiza no momento em que se percebe que há articulação objetiva entre as propagações feitas nos/pelos meios de comunicação e as circunstâncias que afetam da vida.

Entretanto, o que se constata na atualidade é uma dispersão cognitiva decorrente da desarticulação interna entre os níveis operacionais da comunicação (vinculativo, relacional e crítico-cognitivo), ou seja, reforça-se o aspecto mecanicista em relação aos outros dois: o das relações humanas e o do pensamento. É preciso, portanto, ponderar sobre a complexidade do campo e como suas produções afetam os diversos aspectos da vida.

O denso percurso teórico de Muniz Sodré, que perpassa obras anteriores ${ }^{3}$, reconhece a força de homogeneização do pensamento orquestrado pelo mercado, mas também legitima as formas de reação e resistência, principalmente na obra ligada à Educação, que é a base da vertente que seguiremos para pesquisar e aplicar o conceito de Publicidade Social. Desta forma, um dos objetivos centrais deste artigo é compreender a função estratégica da Publicidade Social para a elaboração de metodologias e práticas de ensino-aprendizagem dialógicas e voltadas para o engajamento social.

Demonstraremos a metodologia utilizada no desenvolvimento de algumas campanhas planejadas e realizadas em 2017 para projetos sociais e culturais atuantes na favela carioca, Morro da Providência. Com o intuito de contribuir para a reflexão crítica acerca das relações entre comunicação publicitária, práticas de ensino e retorno social, o artigo consiste em compreender o processo de elaboração das campanhas contextualizando

2. Jornalismo, Editoração, Cinema, Direção Teatral, Relações Públicas, Estudos de Mídia, Rádio e TV, Publicidade e Propaganda etc.

3. Antropológica do Espelho - uma teoria da comunicação linear e em rede, obra publicada nos anos 2000, reconhece a Comunicação Social enquanto campo científico. Logo após, o livro Estratégias Sensiveis: afeto, mídia e política (2006) demonstra como determinados domínios de conhecimento podem ser estratégicos para equalizar as condições cognitivas uma vez que atuem na esfera do sensível. Seguido pela publicação de Reinventando a Educação - Diversidade, Descolonização e Redes (2012), que indica a relevância da educação como brecha para se repensar o caráter totalitário do sistema. Por fim, o raciocínio do autor culmina no Ciência do Comum: notas para o método comunicacional (2015), em que fecha o ciclo iniciado na virada para o século XXI e faz uma avaliação crítica sobre o cenário atual e suas possibilidades de reação. 
e problematizando histórica e teoricamente Publicidade Social e engajamento social na Educação Superior, com ênfase na área de Comunicação Social.

\section{Publicidade Social na Educação Superior na contemporaneidade}

É notório como os interesses do mercado foram tomando conta de todas as esferas da vida, modificando, de forma instantânea, o dia a dia dos indivíduos, independentemente de seu perfil psicográfico. A perspectiva totalizante do capitalismo passou a usar comunicação midiática como estratégia para alinhar subjetividades ao modus operandi das demandas mercantis e, por conseguinte, a contribuir para a construção de cognições habituadas a receber (com apatia) tais referências sem muitas reações.

Nesse sentido, as estratégias, que conduzem sentimentos, emoções e afetos para uma mesma direção, passaram a gerenciar também as cognições. A naturalização das condutas aprovadas e aceitas pelo status quo, na atualidade, estão diretamente ligadas à nova ordem tecnológica que valida as experiências que devem ser lícitas ou não. Consequentemente, o humano se encontra cada vez mais submerso num looping de rápido movimento que comprime o espaço pelo tempo e não percebe uma saída manifesta para tal condição. Questiona-se, portanto: quem financia ou se responsabiliza por tal sistema que parece ser tão absoluto? Quais as possíveis brechas ou saídas, uma vez que, aparentemente, está tudo dominado? Como se engajar em ações que objetivam subverter tal lógica dominante que, em princípio aparenta ser cabal?

Seguindo a linha de pensamento de Sodré, a estratégia de resistência mais lúcida e eficaz está alocada na educação. É na educação que se pode perceber saídas para a sobrevivência e a fortificação do vigor das relações humanas, independentemente do que se veicula nos telejornais ou nos comerciais esteticamente perfeitos exibidos na TV em horário dedicado aos nobres. É nesse ínterim que o curso de Comunicação Social da UFF, mais especificamente a especialização em Publicidade e Propaganda, vem se fortalecendo e se posicionando. Foi o primeiro, e até agora único curso, em todo o território nacional, que já ministrou uma disciplina intitulada Publicidade Social.

O projeto pedagógico inclui as disciplinas que instrumentalizam seus estudantes com as ferramentas que vigem no mercado, a exemplo dos dispositivos móveis, ao mesmo tempo em que complementa o currículo com projetos que, calcados em práticas dialógicas com a Sociedade Civil, trazem à tona as atividades que estimulam o pensa- 
mento crítico relativo às práticas profissionais observadas nos meios de comunicação, no mercado publicitário e na vida ordinária.

Neste artigo, explicitamos o processo de consubstanciação de pesquisas desenvolvidas em projetos que atuam de maneira simultânea e complementar no curso de graduação em Comunicação Social: o LACCOPS (Laboratório de Investigação em Comunicação Comunitária e Publicidade Social), grupo de pesquisa ligado ao PPGMC - Programa de Pós-Graduação em Mídia e Cotidiano, que congrega alunos de pós e de graduação e a AÊ!UFF (Agência de Publicidade Experimental UFF), cuja atuação dos alunos de graduação é primordial para atender projetos reais de pequeno porte, com pesquisa e produção de ponta que são doadas aos clientes ao fim de um ano de trabalho. Partimos do pressuposto de que é pela elaboração de metodologias e práticas de ensino-aprendizagem, dialógicas e voltadas para o engajamento social, que o corpo discente obtém uma formação humanista em função do fortalecimento de uma consciência crítica para aprender a lidar com a realidade. Outro ponto central é discutir engajamento social na educação do ensino superior, sobretudo partindo da prática científica e pedagógica na área da comunicação social, o que envolve disputas epistemológicas, teóricas, políticas e institucionais.

Tais níveis de disputas possuem suas especificidades e interligam-se na práxis. Em última instância, compreendemos práxis, ontologicamente e dialeticamente, como linguagem e objetivação (trabalho). De uma perspectiva materialista dialética, enquanto o trabalho possibilita o intercâmbio material com a natureza, o desenvolvimento das forças produtivas e a criação de valor, a linguagem é a "consciência real, prática" (MARX; ENGELS, 2012, p. 56) e atende a necessidade de intercâmbio entre os homens e os constitui. Além disso, a linguagem possui papel ativo na formação do pensamento conceitual, na abstração, na mediação entre o que é social, herança histórica e cultural, e a dimensão criativa do pensamento (SCHAFF, 1974, p. 50). Antonio Gramsci (1968) defende que a língua seja tratada como expressão de uma visão de mundo e que a evolução quantitativa e qualitativa do domínio linguístico significa "ampliação e aprofundamento da concepção do mundo e da sua história”. (GRAMSCI, 1968, p. 183). Paulo Freire (1979, pp. 91-92) vai além ao afirmar que palavra é práxis, trabalho, direito de todos os homens e não privilégio, daí que a "palavra verdadeira seja transformar o mundo". Enquanto a palavra inautêntica, que não transforma a realidade, é verbalismo, "palavra oca", "alienada e alienante". Considerando a dimensão constitutiva da linguagem e seu caráter histórico, o que nos interessa particularmente aqui é compreender a historicidade e as noções dominantes de engajamento social para, ato contínuo, propor a reapropriação do caráter político deste conceito em base crítica e reflexiva. 


\section{Engajamento Social na educação superior}

Como ponto de partida, precisamos esclarecer o que entendemos como "compreensões dominantes". A principal armadilha epistemológica e política das práticas e sentidos dominantes consiste em travestir de verdade incontestável termos e conceitos moldados historicamente e cotidianamente conforme interesses de classe, por estratégias de poder. Portanto, podem ser questionados, refutados e alterados. $\mathrm{O}$ fato dos sentidos dominantes de engajamento social se tornarem "senso comum", a concepção mais difundida mostra a "efetividade histórica" dessa corrente de pensamento dominante (GRAMSCI, 1968, p. 178). Dialogando com o conceito de hegemonia de Gramsci, Raymond Williams (2005) propõe um modelo teórico no qual em qualquer sociedade e qualquer período histórico há um "sistema central de práticas, significados e valores, que podemos definir propriamente como dominantes e efetivos" (WILLIAMS, 2005, p. 217). O mesmo autor também contribui com nossa argumentação ao abordar o processo de "tradição seletiva", que ocorre dentro de uma cultura dominante e efetiva. Nesse processo, sentidos e práticas são enfatizados, negligenciados, excluídos, reinterpretados ou transformados de maneira a chancelar ou não contestar a cultura dominante e efetiva. Nesse ínterim, práticas e visões de mundo alternativas, ou mesmo de oposição, podem ser ajustadas e aceitas dentro de uma cultura dominante. Ao tratar sobre os modos de incorporação da cultura dominante, Williams $(2005$, p. 217) salienta que as instituições educacionais geralmente são os principais agentes na transmissão de uma cultura efetiva e dominante.

Outro dado que não pode ser ignorado é a maneira como se organiza o regime e o acesso à informação com o controle e vigilância exercidos por gigantes como Google e Facebook, cujos algoritmos favorecem os códigos dominantes de empresas e estados que possuem poder econômico e político para exercerem hegemonia. Se já existisse Internet no início dos anos 1970, quando Raymond Williams e Stuart Hall estavam analisando práticas e códigos dominantes, processos de transmissão, codificação e decodificação, os autores certamente dariam atenção para o modo como essas categorias podem ser pensadas na sociedade da informação. Em uma rápida pesquisa no Google, podemos perceber como se organiza o acesso às informações e às concepções dominantes de engajamento social. O conceito aparece fundamentalmente ligado ao mundo corporativo, geralmente a estratégias de marketing social e comunicação organizacional e também às estratégias empresariais, para obter vantagem competitiva em um ambiente de forte concorrência. O sentido de engajamento é associado eminentemente ao alinhamento da cultura organi- 
zacional de empresas junto aos stakeholders, os públicos estratégicos de uma organização: clientes, funcionários, acionistas, fornecedores, sindicatos, sociedade, comunidade, governo etc. Trata-se de versão repaginada de objetivo a ser alcançado em estratégias de comunicação interna, também chamadas de endomarketing, que se acentuaram durante a década de 1990 no Brasil: conseguir com que o funcionário ou, eufemisticamente, o colaborador, "vista a camisa" da organização. A transformação do conceito de engajamento, ocorrida ao longo dos anos nas universidades, não segue caminhos totalmente distintos do mercado, haja vista que tanto em universidades públicas como privadas há áreas do conhecimento, linhas de pensamento e pesquisa alinhadas com as demandas, propostas e estratégias mercadológicas.

A palavra engajamento possui um sentido eminentemente social, comunicacional e político, afinal pressupõe relação, vínculo, comprometimento, contato, sociabilidade com algo, causa ou alguém. O fato de precisar inserir o vocábulo "social", ou mesmo "político" ou "cívico", para significar determinado sentido de engajamento, denota que temos aí uma virada linguística marcada pela ampla relativização do conceito. Mudanças discursivas costumam ocorrer em processos mais amplos de mudanças sociais e culturais (FAIRCLOUGH, 2001), que nem sempre são claras aos envolvidos. Etimologicamente, engajamento vem do francês medieval engagier, de en gage, "sob compromisso, sob promessa", de en, “fazer", mais gager, "compromisso, garantia”. Destarte, engajamento evoca ter compromisso com algo. Embora, historicamente, tenhamos proeminência no uso de engajamento como "comprometimento" político de sujeitos e práticas que visam à transformação social: intelectual engajado, professor engajado, literatura engajada, arte engajada, mais recentemente se destaca o uso corporativo e publicitário do termo. Nesse ínterim, o conceito de engajamento é utilizado no mundo do trabalho e nas redes sociais como o alinhamento ideológico entre empresa, marcas e seus públicos. Nosso principal objetivo nessa discussão é buscar caminhos para contribuir com a reapropriação do sentido político de engajamento.

Abordar o tema engajamento dos estudantes em uma universidade, particularmente em sala de aula, insta-nos a debater metodologias de ensino-aprendizagem. Uma armadilha deste debate é o fetichismo do uso da tecnologia em sala de aula. Não negamos a sua importância, mas compreendemos que a discussão sobre o método precede o uso da tecnologia. A metodologia das disciplinas Planejamento de Campanha e Realização de Campanha como Agência UFF, alimentada pelo trabalho de pesquisa e extensão do LACCOPS, envolve o protagonismo dos discentes no planejamento e realização de uma 
campanha publicitária. O trabalho desenvolvido por eles, com nossa orientação, envolve o manuseio e domínio de hardwares, softwares, máquinas fotográficas, celulares etc. Enfim, há o uso de tecnologia e a intensa participação dos estudantes no processo de ensino-aprendizagem, proporcionando características de metodologias consideradas inovadoras, como a "sala de aula invertida". Não obstante, entendemos que a principal "inversão" com a qual buscamos trabalhar é com relação ao olhar dos estudantes sobre seu campo do conhecimento, o que envolve o olhar sobre a cidade, seus territórios, as pessoas, carências, ideias, narrativas, projetos, bem como a relação entre os sujeitos, a cidade e a história. O bom comunicador, o bom publicitário, precisa conhecer gente, saber ouvir, falar, olhar e representar falas, sentimentos, desejos. Com a mirada da publicidade social e a metodologia do trabalho em agência, o estudante aprende as técnicas da sua futura profissão e possui a oportunidade de se engajar, na acepção política do termo, com a vida da cidade e do estado quase sempre invisibilizada: a vida dos excluídos, pobres e miseráveis. Para esse intuito de pensar sobre a tarefa de conciliar formação prática e teoria crítica com perspectiva cidadã, política e humanista, dois autores possuem contribuições inestimáveis: Antonio Gramsci e Paulo Freire.

Gramsci (1966, p. 37) entende que toda relação de hegemonia é uma relação pedagógica. A significação histórica de um filósofo individual vai se dar pela "relação ativa entre ele e o ambiente cultural que ele quer modificar, ambiente que reage sobre o filósofo e - obrigando-o a uma permanente autocrítica - funciona como 'professor'". Essa reflexão orienta nossa metodologia na prática docente em algumas direções. No plano da autorreflexão, como educadores sobre o olhar para o conjunto das relações sociais nas quais estamos inseridos. Dessa maneira, a sociedade que nos cerca, as contradições históricas, as pessoas e territórios marginalizados, explorados e expropriados precisam ser objeto do nosso conhecimento e dos processos de ensino-aprendizagem que formarão novos comunicadores sociais. E, mais importante, tanto os estudantes como as pessoas dos projetos sociais com os quais trabalhamos são intelectuais com capacidade para o diálogo e a crítica geradores de novos sentidos. E nosso grande desafio é conseguir construir junto a nossos interlocutores, estudantes e agentes sociais das favelas, essas pontes de diálogos criativos e construtivos. Para isso, Paulo Freire tem também grandes contribuições.

4. Para conhecer o relato de uma experiência com essa metodologia ver: LEMOS, André; PERL, Lara. Comunicação e Tecnologia Uma experiência de "Classe Invertida". Comunicação \& Educação, São Paulo, v. 20, n. 1, p. 127-139, maio, 2015. Disponível em: <https://www.revistas.usp.br/comueduc/ article/view/84709>. Acesso em: 23/02/2018. 
Na perspectiva dialógica freireana (FREIRE, 1977; 1979) todos somos sujeitos cognoscentes, mediados pelo mundo, pelas estruturas, relações sociais, com capacidade para pronunciar e transformar a realidade. A dialogia freireana se expressa até mesmo na maneira de se referir aos sujeitos envolvidos no ato pedagógico, cultural e comunicacional da educação: educador-educando e educando-educador, co-enunciadores e interlocutores em contínua formação.

\section{A origem da publicidade social no Ensino Superior: ensino, pesquisa e extensão}

A Publicidade e Propaganda é uma atividade originária do mercado, que só obteve um amparo legislativo por volta dos anos de 1970 e começou a ter um reconhecimento acadêmico décadas mais tarde, pelo final do século XX, quando uma discussão mais acirrada sobre o subcampo emergiu no Ensino Superior.

O panorama da Publicidade e Propaganda passou a se constituir em duas vertentes que até hoje ainda não chegam a um consenso: de um lado, certificado pelo texto da lei, o mercado trata os termos como sinônimos, como se as atividades de resumissem à perspectiva técnico-comercial; do outro lado, a academia se esforça para diferenciar os vocábulos, pois começou a observar, com um olhar mais atento, as diversas expressões publicitárias emergentes. Para a academia, apesar de considerar sua conjuntura técnica elementar, as pesquisas em Publicidade e Propaganda desenvolvidas nas/pelas Universidade acrescentaram um novo prisma investigativo, incluindo em suas averiguações as atividades publicitárias que já aconteciam nos centros urbanos, nas favelas, nos movimentos sociais e como as empresas e grandes corporações estavam lidando com o cenário contemporâneo. Ou seja, atualmente não é possível fazer pesquisa em Publicidade de forma desassociada da extensão. Cabe salientar que compreendemos extensão a partir da perspectiva dialógica proposta por Paulo Freire (1977). O educador brasileiro realiza análise semântica do termo extensão e conclui que a palavra denota "transmissão", superioridade de quem entrega e inferioridade de quem recebe, mecanicismo e invasão cultural. Sendo assim, "o conceito de extensão não corresponde a um que-fazer educativo libertador" (FREIRE, 1977 , p. 23). Freire defende o uso da palavra comunicação para tratar da relação entre educador-educando e educando-educador em uma atividade pedagógica que envolva a sociedade. 
O diálogo é o encontro amoroso dos homens que, mediatizados pelo mundo, o "pronunciam", isto é, o transformam, e, transformando-o, o humanizam para a humanização de todos. Este encontro amoroso não pode ser, por isto mesmo, um encontro de inconciliáveis. Não há nem pode haver invasão cultural dialógica; não já manipulação nem conquista dialógicas: estes são termos que se excluem (FREIRE, 1977, p. 43).

Foi a partir da aproximação com os projetos de extensão que o engajamento social ganhou força no curso de Publicidade e, consequentemente, ampliou o espectro que permitiu que os pesquisadores, estudantes, professores e técnicos do Laccops percebessem as novas configurações da área, como, por exemplo, a Publicidade Social.

Por mais que pareça contraditório, uma das características marcantes do curso de Publicidade e Propaganda da UFF é que uma parte significativa do corpo docente tem uma densa formação tanto na Comunicação Comunitária, como um sólido caminho trilhado no mercado publicitário. A junção das experiências somadas a uma consistente metodologia de pesquisa voltada para os projetos de extensão inaugurou no meio acadêmico uma perspectiva inovadora para aprendizado e prática efetiva da Publicidade: a Publicidade Social.

Uma precípua metodologia ligada à revisão bibliográfica aliada à pesquisa de campo, mais precisamente à pesquisa-ação, permitiu ao grupo de professores perceber como as técnicas da publicidade de caráter comercial vinham sendo aplicadas na práxis diária nos espaços externos da Universidade. Foi na convergência de pesquisa e extensão que os professores da área foram e ainda estão reestruturando continuamente o projeto pedagógico do curso.

\section{AÊ UFF e Laccops: metodologias e práticas dialógicas para o engajamento social}

Dentre muitos projetos do curso de comunicação, os dois diretamente ligados à Publicidade Social são AÊ!!UFF e LACCOPS. No ano de 2017, a integração dos dois projetos permitiu o desenvolvimento de uma ação no Morro da Providência. Um exemplo prático de Publicidade Social se constituiu no projeto coletivo realizado em 2017 pela UFF, a partir do avanço da Publicidade Comunitária (a realizada no microespaço) e que tem características comerciais, só que voltadas para a economia local.

O diálogo entre LACCOPS e o Morro da Providência, a primeira favela do Brasil, localizada na região portuária da cidade do Rio de Janeiro, teve início quando o LAC- 
COPS ganhou, no final de 2016, o edital da Secretaria de Cultura do Estado do Rio de Janeiro para realizar o Projeto Publicidade Comunitária: uma produção coletiva entre a juventude do Morro da Providência e a Juventude da Laccops. O projeto Provi Criativa: A melhor visão do Morro, assim denominado pelos estudantes participantes do LACCOPS, fez parte do programa Territórios Culturais RJ e Favela Criativa. O projeto foi realizado com o patrocínio da secretária de cultura do Estado do Rio de Janeiro, a Agência Nacional de Energia Elétrica (Aneel) e a Light. A realização das atividades ocorreu entre 17/08/2017, quando houve a primeira oficina de audiovisual, e o dia 20/09/2017, data da premiação dos melhores vídeos. Os três melhores vídeos foram premiados com dois aparelhos celulares, comprados com a verba do Edital: um para o jovem realizador e um para o responsável pelo projeto do Morro da Providência.

O objetivo principal do Provi Criativa foi promover um ambiente de diálogo e engajamento social entre os alunos da Universidade Federal Fluminense (UFF), jovens moradores da Providência e os projetos locais, possibilitando mais visibilidade aos projetos, a partir do conteúdo criado e produzido pelos jovens. Realizamos oficina de audiovisual, na qual o conteúdo do vídeo foi criado e produzido por aparelho celular, com a participação de três turmas com sete alunos cada, totalizando 21 vídeos produzidos por jovens do Morro da Providência e de Nova Iguaçu ${ }^{5}$, orientados por professores e estudantes do LACCOPS. Foram sete projetos do Morro da Providência contemplados pelas oficinas de audiovisual: Epicentral, Galeria Providência, Rolé dos Favelados, Providenciando Vidas, Cineclube Revolucionário, Meu Cantinho Verde e Impacto das Cores.

No primeiro final de semana do mês de abril de 2017, fomos em uma equipe do LACCOPS participar do Rolê dos Favelados e fazer uma reunião com os responsáveis por cada projeto na Epicentral. O Rolê dos Favelados, idealizado pelo guia Cosme, é um guiamento pelas favelas do Rio realizado por seus favelados e faveladas militantes por direitos humanos. O Espaço de Permacultura da Central do Brasil (Epicentral) é uma casa colaborativa no Morro da Providência, que é o local onde se realizam reuniões e em que se aglutinam os projetos e ativistas atuantes no Morro. A dinâmica da reunião foi a expressão da perspectiva dialógica em educação, na qual "o educador refaz a sua "cognosibilidade" através da "cognosibilidade" dos educandos". O diálogo é essa "relação epistemológica" em que o objeto do conhecimento vincula os sujeitos cognitivos levando-os a refletir conjuntamente (SHOR; FREIRE, 1986, p. 65). Em perspectiva

5. Inicialmente, estava prevista somente a participação de jovens moradores do Morro da Providência, mas o forte desejo de participação por parte de jovens de Nova Iguaçu, juntamente com a possibilidade de vagas e do que previa o Edital, foi aberta a exceção. 
dialógica, todos ali éramos educadores-educandos. Inicialmente, tivemos um momento de tensão no ar. É bastante compreensível a desconfiança por parte de moradores das favelas e ativistas de movimentos populares e sociais com relação a "projetos" e pesquisas realizadas por estudantes e professores. Ninguém quer se sentir "objeto", cobaia, sem ter contrapartida clara nessa relação. E, de fato, embora reconheçamos o valor intrínseco à ciência, enxergamos muitas vezes a supremacia do pesquisador na relação entre sujeitos comunicantes, na produção científica em que os "objetos" são pessoas. Portanto, tudo nessa relação entre Universidade e Sociedade deve ser muito bem dialogado e esclarecido, inclusive o retorno aos envolvidos.

Depois dessa tensão inicial, dialogando e gerando novos sentidos, fomos nos transformando mutuamente. A principal questão que emergiu nesse diálogo regenerador foi a demanda premente, exposta pelos coordenadores dos projetos, de inteligência publicitária para atender necessidades de seus projetos. Pormenorizando: eles viram contribuições muito positivas nas propostas de oficinas de audiovisual e tudo o que havia no edital conquistado, mas eles precisavam de coisas ainda mais fundamentais naquele momento, como logomarca e estratégias mais efetivas para suas ações em redes sociais. E nós tínhamos como oferecer isso por meio da AÊ! UFF. Teve início ali uma relação frutífera para todas e todos os envolvidos. Assim, durante todo o ano de 2017, atendemos na AÊ! UFF os projetos Cineclube Revolucionário, Meu Cantinho Verde e Providenciando Vidas. Todos os três projetos resultaram em campanhas bem sucedidas que, em síntese, envolveram: o Planejamento de Campanha desenvolvido durante um semestre, com análise da marca, do público, do território, definição de estratégias, objetivos e táticas de comunicação; e a Realização da Campanha, durante um semestre, com o desenvolvimento de um plano de comunicação integrada, a realização de estratégias e táticas de comunicação publicitária, a aplicação das decisões estratégicas do planejamento nos processos de criação, mídia e produção. Todo o processo contou com a participação dos responsáveis pelos projetos por meio de diálogos, em meios diversos, e encontros presenciais na UFF e no Morro da Providência. Vamos destacar brevemente os principais momentos e resultados da campanha ${ }^{6}$ realizada para o Cineclube Revolucionário, a mais exitosa entre os três projetos realizados: pelo processo dialógico do trabalho e pelo resultado final apresentado.

6. A campanha foi realizada pelos discentes: Beatriz Paiva, Bruna Andrade, Claudia Sobral, Diannie Lopes, Fernanda Areas, Gabriela Carvalho, Ian Sobroza, João Alves, Lucas Linhares e Taynara Cabral. O book final desenvolvido pelos estudantes, juntamente com demais produtos realizados pela AÊ! UFF está em: < https://portifolioaeuff.wordpress.com/>. Acesso em: 26 fev 2017. 
Durante a disciplina de Planejamento de Campanha, geralmente as equipes de trabalho, compostas por cinco a oito discentes, desenvolvem o Planejamento; e o responsável pelo projeto, o cliente, escolhe a melhor proposta em apresentação realizada em sala de aula, na UFF. No ano de 2017, excepcionalmente, pela demanda apresentada pelos projetos do Morro da Providência, nós atendemos simultaneamente três projetos da favela e mais outro ${ }^{7}$, que estava aguardando oportunidade de participação. Dessa maneira, o procedimento adotado foi diferente: os responsáveis vieram apresentar seus projetos e cada equipe escolheu aquele que gostaria de trabalhar. Os discentes que escolheram o Cineclube Revolucionário demonstraram grande sensibilidade e engajamento social com o projeto, a responsável, Fatinha Lima, e sua parceira Márcia Raquel, durante toda a campanha. Conforme o avanço dos tópicos do conteúdo, os discentes desenvolvem cada etapa do Planejamento de Campanha: informações sobre o projeto, que compõem o Briefing, o cenário de atuação, definição do problema, posicionamento, conceito, slogan, públicos, objetivos da campanha, estratégia de comunicação e ações táticas.

O Cineclube Revolucionário do Morro da Providência foi fundado em agosto de 2016, a partir da necessidade de arte, cultura, lazer e mais integração social na favela, tendo como expectativa realizar sessões gratuitas, promover o encontro de moradores, estimular a ocupação de espaços ociosos através de sessões em locais públicos e fomentar o acesso ao cinema e às artes audiovisuais em geral, sempre tendo como propósito trazer novas perspectivas e referências dentro daquela realidade. O Cineclube Curumim Revolucionário surge na quarta sessão, com a crescente frequência de crianças, quando criaram um cineclube exclusivamente para o público infantil, com sessões voltadas e pensadas para menores de 16 anos de idade. O conceito criado na campanha é sintetizado na frase: "A margem é a imagem", que mostra o objetivo da campanha de "trazer a margem para o centro da imagem, romper para mudar". O slogan definido foi: "Luz, Câmera, Revolução". Com a percepção de que o nome "Revolucionário", embora coerente com a proposta do Cineclube, poderia transmitir aos moradores a ideia de algo distante da realidade deles, os estudantes avaliaram que seria necessário: "definir um nome com grafia, sonoridade e sentido de fácil familiarização ao universo verbal da comunidade, para que depois o Cineclube possa se apresentar como Revolucionário” (ALVES et al., 2017). A equipe, então, propôs o nome Favela Cineclube e passou a criar estratégias específicas para o Favela Cineclube e a Edição Curumim. Em síntese, a equipe reestruturou toda a comunicação da marca, elaborou a identidade visual completa, a linguagem textual,

7. O outro projeto era de uma marca de manteiga Ghee e vegana, chamada A Moreninha, de ex-aluno de Comunicação Social da UFF e sua esposa, moradores da Ilha de Paquetá. 
a criação de um padrão para as postagens em redes sociais, a frequência de conteúdo e elaboraram uma vaquinha virtual, na qual arrecadaram $\mathrm{R} \$ 2.800,00,233 \%$ a mais do que o inicialmente previsto. Com o dinheiro arrecadado, desenvolveram também papelaria: case/portfólio do Favela Cineclube, cartão de visitas, lambe-lambe e camisetas. Para a conclusão do projeto, realizaram um workshop em que ensinaram as responsáveis, Fatinha e Márcia Raquel, como manter as ações em andamento, mesmo com o fim da disciplina: como fazer campanha nas redes sociais, orientações sobre a identidade da marca, possíveis parcerias, projetos etc.

O conceito sobre Publicidade Social desenvolvido LACCOPS e aplicado na AÊ! UFF começou a ser pensado há mais ou menos cinco anos atrás e, apesar de já ser abordado em outros países ${ }^{8}$, aqui no Brasil tem uma característica diferenciada. Está diretamente ligada ao conceito de engajamento social. Basicamente, trata-se de um conceito guarda-chuva que se manifesta na dilatação das práticas ligadas à Publicidade Comunitária.

A publicidade comunitária, também tem objetivo comercial, com a diferença de primar pela renda digna para seus componentes sem exploração do trabalhador e, ao contrário da tradicional de mercado, tem como intuito aquecer a economia e os produtores locais fortalecendo o micro-ambiente e valorizando o trabalho da/pela e para a comunidade através do fortalecimento do vínculo. Portanto, uma publicidade Comunitária também tem cunho comercial, mas está diretamente ligada à fortificação dos benefícios voltados à localidade. A Publicidade Comunitária trabalha com práticas comerciais para o fomento da economia local e para divulgação da produção local para um público mais amplo, além do público interno. O ponto é que a Publicidade Comunitária é feita na, pela e para a comunidade. Se empenha em dar visibilidade positiva aos talentos (culturais, artísticos, comerciais, alimentícios, científicos, etc) do lugar e tem por objetivo reverter os benefícios conquistados com suas ações para a própria localidade. (SALDANHA, 2017, on-line).

O Laccops e reúne periodicamente para discutir uma possível tipologia, uma vez que existem várias esferas de atuação para a Publicidade Social com enfoque colaborativo. No entanto, ainda não há nomenclatura definida, tampouco exemplos de diversidade para esta nova possibilidade de se pensar a Publicidade. Como eixo central, a Publicidade Social tem o intuito de incluir os membros da Sociedade Civil nas atividades e, portanto, está atenta para as possibilidades de projeção da prática comunicativa para uma escala mais ampla capaz de fazer interface com a Sociedade Civil, com enfoque nas questões que afetam o cotidiano do cidadão comum.

8. O conceito de Publicidade Social equiparado ao de Marketing Social é utilizado na Espanha e nos Estados Unidos. Não é a proposta que está sendo elaborada pelo Laccops. 


\section{Considerações finais}

Se na prática hegemônica o subalterno toma para si a causa do dominador como se fosse sua, a Publicidade Social tem a possibilidade de estimular o caminho reverso. Há uma mudança de eixo na produção, na linguagem e nas veiculações. O processo é decorrente da popularização dos novos aparatos tecnológicos cada vez mais acessíveis e da inclusão do receptor na dinâmica de produção. Ou seja, o receptor entra na causa do outro como se fosse dele. Compreende, ainda que momentaneamente, que contribuiu para o objetivo da causa e participa do processo criativo, das partes de produção, de espalhamento e publicização do tema tratado. Este é o movimento de ampliação.

Quando tal prática se dá na ampliação da escala de suas realizações e envolve a Sociedade Civil em uma das etapas dos projetos, (na produção, na implementação ou na veiculação/ação prática) chamamos de Publicidade Social. São formatos alternativos de conquista e autonomia que admitem a participação efetiva de membros exteriores, ou agentes externos, muitas vezes representados por integrantes das Universidades ou cidadãos comuns. É uma publicidade que extrapola o âmbito da relação e da interação conquistada nas redes sociais e parte para o estreitamento dos laços de forma vinculativa.

Entendemos que é na fronteira, compreendida politicamente e socialmente como lugar da alteridade, de encontro, desencontro e contradição, que se encontra o maior potencial para o desdobramento da comunicação política emancipatória, para a integração crítica e a transformação radical (Bastos, 2015, p. 14). A fronteira política se encontra também na sala de aula, na universidade, felizmente mais inclusiva, embora distante do que almejamos, mas é realmente cognoscível fora da sala de aula, no diálogo com as classes populares, no conhecimento da realidade social e suas estruturas de reificação, exploração, expropriação e opressão. Entretanto, podemos também trazer esse diálogo e realidade para os espaços tradicionais de formação, seja contribuindo para que a universidade venha a ser cada vez mais ocupada pelas classes populares, no ensino, na pesquisa e na extensão, ou seja trazendo essa realidade pela produção científica politicamente engajada, no que jamais renunciaremos. Afinal, "a leitura crítica do mundo é um que-fazer pedagógico-político indicotomizável do que-fazer político-pedagógico, isto é, da ação política que envolve a organização dos grupos e das classes populares para intervir na reinvenção da sociedade" (FREIRE, 2000, p. 42).

Os dois semestres de construção de Publicidade Social entre AÊ!UFF, LACCOPS e Morro da Providência proporcionaram momentos de muito aprendizado afetuoso entre edu- 
cadores-educandos, educandos-educadores, e vice-versa. Os sorrisos e lágrimas de estudantes e responsáveis pelos projetos, que surgiram durante o diálogo sobre a campanha que realizaram, objeto comum de conhecimento, mostraram que emoção, amor e afeto rimam bem com engajamento social, conhecimento crítico e reflexivo. Nossa sensação como educadores-educandos, responsáveis pelo projeto de ensino, pesquisa e extensão ali consubstanciado, não poderia ser melhor. Conquanto tenhamos clareza das limitações da nossa atividade para realizar as transformações profundas que almejamos para a sociedade, pudemos dar pequena contribuição com nosso trabalho criticamente responsável e socialmente engajado.

\section{Referências}

ALVES, João; ANDRADE, Bruna; AREAS, Fernanda et al. Campanha Favela Cineclube. Material desenvolvido pelos discentes do curso de graduação em Comunicação Social-Publicidade e Propaganda, durante as disciplinas Planejamento de Campanha e Realização de Campanha. Niterói: Universidade Federal Fluminense, 2017.

BASTOS, Pablo Nabarrete. Marcha dialética do MST: formação política entre campo e cidade. 2015. Tese (Doutorado em Interfaces Sociais da Comunicação) - Escola de Comunicações e Artes, Universidade de São Paulo, São Paulo, 2015. Disponível em: <http://www.teses.usp.br/teses/ disponiveis/27/27154/tde-29062015-151022/>. Acesso em: 24 jul. 2018.

FAIRCLOUGH, Norman. Discurso e mudança social. Brasília: Editora Universidade de Brasília, 2001.

FREIRE, Paulo. Extensão ou comunicação? Rio de Janeiro: Paz e Terra, 1977.

. Pedagogia do Oprimido. Rio de Janeiro: Paz e Terra, 1979.

. Pedagogia da indignação: cartas pedagógicas e outros escritos. São Paulo: Editora

UNESP, 2000.

GRAMSCI, Antonio. Concepção dialética da história. Rio de Janeiro: Civilização Brasileira, 1966. . Os intelectuais e a organização da cultura. Rio de Janeiro: Civilização Brasileira, 1968.

LEMOS, André; PERL, Lara. Comunicação e Tecnologia Uma experiência de "Classe Invertida". Comunicação \& Educação, São Paulo, v. 20, n. 1, p. 127-139, maio, 2015. Disponível em: <https://www.revistas.usp.br/comueduc/article/view/84709>. Acesso em: 23/02/2018. 
MARX, Karl; ENGELS, Friedrich. Ideologia Alemã. São Paulo: Martin Claret, 2012.

SALDANHA, Patrícia. Publicidade Social: uma posição brasileira inicial sobre as possibilidades contra-hegemônicas da comunicação publicitária. In: Propesq, 2017. Disponível: <http://docs. wixstatic.com/ugd/bb9c7e_c7fb97b3e7fd4fb89a7a38d34c4335c8.pdf $>$. Acesso em: 24 jul. 2018.

SCHAFF, Adam. Linguagem e conhecimento. Coimbra: Livraria Almedina, 1974.

SODRÉ, Muniz. A Ciência do Comum: Notas para o Método comunicacional. Petrópolis: Vozes, 2015 .

SHOR, Ira; FREIRE, Paulo. Medo e Ousadia - O Cotidiano do Professor. Rio de Janeiro: Paz e Terra, 1986.

WILLIAMS, Raymond. Base e estrutura na teoria cultural marxista. Revista USP, São Paulo, n. 65, p. 210-224, mar.-maio 2005. 